\title{
Distress Resolution in Nigerian Banking Sector: The Role of Assets and Liabilities Management
}

\author{
Folajimi Festus Adegbie ${ }^{1}$, T. O. Asaolu ${ }^{2}$ \& E. P. Enyi ${ }^{1}$ \\ ${ }^{1}$ Department of Accounting, Babcock Business School, Babcock University, Ota, Nigeria \\ 2 Department of Accounting, Obafemi Awolowo University, Ife, Nigeria \\ Correspondence: Dr. Folajimi Festus Adegbie, Department of Accounting, Babcock Business School, Babcock \\ University, Ota, Ogun State, Nigeria. Tel: 234-802-323-3204. E-mail: folaadegbie@yahoo.com
}

Received: August 2, 2012

doi:10.5430/ijfr.v4n3p70

\author{
Accepted: May 31, 2013 \\ Online Published: June 24, 2013 \\ URL: http://dx.doi.org/10.5430/ijfr.v4n3p70
}

\begin{abstract}
The banking industry has lost its position as the bedrock of Nigerian economy due to abysmal performance of the economy. The industry is known to have contributed in no small measure to the development of the economy. This industry is the enabling hub of national and global payment systems, which facilitate trade transactions within and amongst numerous national, regional and international economic units and by so doing; it enhances commerce, industry and exchange. Poor investment policy in the industry has contributed negatively to large non-performing loans and advances, financial distress and institutions liquidation. The objective of this paper is to assess the investment policies in the banks with a view to suggesting better policy for better management of assets and liabilities for distress resolution. The research is empirical. The study covers the banking industry with the use of corporate questionnaire to gather data from each of the sample representatives which are twenty four universal banks and five industry regulators. Multivariate Analysis of Variance (MANOVA) was used to compute the collated data. The results show that there is poor management of assets and liabilities, poor investment policies in the industry, the banks grow assets more than liabilities, the banks resulted into using depositors' money to acquire assets and they failed to comply with Central Bank of Nigeria monetary policies. The paper recommends among others that the industry and the regulators and supervisory agents should institute a good and sound investment policy for effective management of assets and liabilities in the industry.
\end{abstract}

Keywords: accountability, distress, deregulation, legislation, mismatch, resolution, sustainable performance, transparency, undercapitalization

\section{Introduction}

The assets and liabilities of the bank's balance sheet are nothing but future cash inflows or outflows. With a view to measure the liquidity and interest rate risk, banks use of maturity ladder and then calculate cumulative surplus or deficit of funds in different time slots on the basis of statutory reserve cycle, which are termed as time buckets. As a measure of liquidity management, banks are required to monitor their cumulative mismatches across all time buckets in their statement of structural liquidity by establishing internal prudential limits with the approval of the board/management committee. The banking sector is part of Nigerian Financial System, and financial system refers to the totality of the regulatory and participating institutions, including financial markets and instruments involved in the process of financial intermediation. The major objectives of investing in the banking sector are to provide financial services to the economy and earn compensatory returns on capital employed. The banking industry is the enabling hub of national and global payments system by facilitating trade transactions within and amongst numerous national, regional and international economic units and by so doing, it enhances commerce, industry and exchange. According to Onoh (2002:10-13), the establishment of modern banking in Nigeria dates back to the colonial era when the African Banking Corporation was formed in 1892 to distribute currency notes of the Bank of England for the British treasury. Subsequent developments were encouraged by colonial entrepreneurs who needed banking institutions to back up the colonial trade. In the bid to address the credit needs of indigenous enterprises, Nigerians later ventured into the banking business, initially through private individuals and later through deliberate government policy. 
Central Bank of Nigeria (CBN) and Nigerian Deposit Insurance Corporation (NDIC) (1995) collaborative study reveals that several other foreign and a host of indigenous banks were established. The establishment of indigenous banks was initially propelled largely by nationalistic consciousness rather than the existence of relevant resources, including basic skilled manpower for running such institutions. Consequently most of the early indigenous banks collapsed in rapid succession the same way they were established. Banks that failed during this period were largely those with problems of inadequate capital, fraudulent practices and bad management. According to Olalusi (1992:13-59), discriminatory lending practices by expatriate banks spurred indigenous entrepreneurs into banking. It was the imperative of economic nationalism and economic development which were primarily responsible for government interest in banking. As the country prepared for political independence in 1960, efforts to establish banks were intensified by some nationalist who rightly recognized the pivotal role banks play in economic emancipation and development. This also accounted for the takeover of the surviving indigenous banks by the regional governments; particularly after 1954. The banks were expected to accelerate the economic and social development of the regions by bringing banking services to the doorsteps of the people in the regions. It was unfortunate that the establishment of the government owned banks which started out as a blessing to indigenous banking became its bane.

Thus the banking Act 1952 was put in place as premier legislation on banking business in Nigeria. The major characteristic of the colonial era was the unregulated banking practice, which led to the phenomenal distress and liquidation of banks.Onoh (2002:15-30) in his study gave the following reasons for the collapse of the pioneer indigenous banks:

1). Absence of regulatory authorities and lender of last resort. The West African Currency Board (WACB) established in 1912 was not endowed with regulatory and supervisory powers.

2). Undercapitalization and over branching.

3). They carried disproportional overhead bills, which generated debt equity ratios inconsistent with the level considered appropriate for sound banking operations.

4). Poor management and fraud. They practiced lending without scrutinizing the credit worthiness of borrowers. Advances were made to finance activities, which yielded no returns; fraud was rampant because there was no supervisory authority to detect frauds.

5). Poor customer patronage. Colonial government patronage could not be attracted by indigenous banks because expatriate firms patronized only the expatriate banks to the neglect of indigenous banks.

6). There was poor liquidity because there was no authority to establish and enforce a minimum liquidity ratio for the banks. There was no definition of what should constitute the liquid assets of banks until the Banking Act of 1962 when this was stated and approved.

7). There was poor quality manpower which made balance sheet analysis impossible by indigenous banks. There was no statistical analysis of the trends of deposits, bad and doubtful debts and their implications to the banks operations. There was no good management of assets and liabilities of the banks.

AllBankingSolutions.com (2000) defines assets and liabilities management as a comprehensive dynamic framework for measuring, monitoring and managing the market risk of a bank. It is the management structure of balance sheet (liabilities and assets) in such a way that the net earnings from interest are maximized within the overall risk-preference of the institutions. The Asset and Liabilities functions extend to liquid risk management, management of market risk, trading risk management, funding and capital planning and growth projection.

According to CBN (2004:1), following the deregulation of the Nigerian financial sector in 1986 during the era of structural adjustment programme (SAP), the banking industry witnessed remarkable growth, both in the number of deposit money banks and other types of financial institutions. However, in the early 1990s, Nigerian banking institutions faced many challenges, including increased competition and harsh economic conditions. Against this background, the incidence of financial sector distress induced by undercapitalization, liquidity crisis and high degree of non-performing loans characterized the banking industry in Nigeria. Some of the banks were faced with the threat of liquidation, while some were resuscitated as a result of the timely intervention of the regulatory authorities. As a way of minimizing the distress in the banking system, the Central Bank of Nigeria in 1990 introduced the prudential guidelines on early recognition of loan losses and requires banks to make adequate provisions for bad and doubtful debts, a factor which was responsible for the insolvency of some banks. The Central Bank of Nigeria explained that based on bank examination reports, the supervisory authorities drew the attention of the Boards and Management of distressed banks to a number of shortcomings such as poor credit policy, large portfolio of non-performing assets, 
weak internal controls and insider abuses. All the recommendations made to salvage the banks were unheeded. In order to sanitize the banking system and install market discipline, the licenses of some banks were revoked in the system in 1992, 1994, 1998 and 2005 because of distress as they could not continue in operation.

According to Eghodaghe (1993) and cited by CBN and NDIC (1995), a financial institution in distress is usually one where the evaluation depicts poor condition in all or most of the five performance failures stated thus (a) gross undercapitalization in relation to level of operation. (b) high level of classified loans and advances (c) illiquidity reflected in the inability to meet customer's cash withdrawals.(d) low earnings resulting from huge operational losses and (e) weak management as reflected by poor credit quality, inadequate internal controls, high rate of frauds and forgeries, and labour turnover.

\subsection{An Overview of the Nigerian Economic Growth}

According to USAID (2012), Nigeria has enjoyed strong economic growth over the past-seven years, but poverty is still a major concern. While oil accounts for 95percent of export earnings and 85 percent of government revenue, agriculture which employs 70 percent of the population accounts for only 2.6 percent of export. Economic growth in Nigeria is constrained by inadequate infrastructure, electricity, incentives and policies that promote private sector development, and poor access to quality education. Sustained broad-based economic growth and poverty reduction are critical to Nigerian economic stability. Nigeria economic growth is also constrained by insufficient electricity generation which results in a lack of reliable and affordable supply of power. Nigeria economy has had a truncated history. In the period 1960-1970, the Gross Domestic Product (GDP) recorded 31 percent growth annually. Oil boom of 1970-78 grew GDP position by 6.2 percent annually which was remarkable. In the 1980s, GDP had negative growth rates.The GDP responded positively to the structural adjustment of 1988-1997 by recording a positive growth rate of 4.0percent. The manufacturing sectors which had a positive growth rate after independence recorded negative growth of between -3.2percent and 2.9percent.The economy which never experienced double-digit inflation during the 1960s, enjoyed a 23 percent inflation between 1976 and 1988. Decreased to 11.8 percent in 1979, jumped to 41 percent and 72.8 percent in 1989 and 1995 respectively. By 1998 inflation rate reduced to 9.5 percent from 29 percent in 1996 (Ekpo and Umoh, 2012). The corruption and mismanagement of Nigeria post-colonial government legacy has prevented the channeling of Nigeria abundant natural and human resources-especially its wealth in crude oil into lasting improvements in infrastructure and the construction of a sound base for self-sustaining economic development. This has made Nigeria one of the less developed and poorer countries of the world. Nigeria has the potential to become a major economic power if the leaders of the nation resolve to learn from the past mistakes and harness the country's rich natural and human resources for a productive and sustained effort to promote economic development. Udah and Obeguagu (2011) were of the view that Nigeria is recognized globally as a country with great potential required to achieve rapid econkmic development and growth. As the biggest economy in West Africa, it has the capacity to acquire the right technology, physical and human capital to fast track the pace of economic development and growth, the significant gaps in the availability and quality of infrastructure, human capital and the level of rent seeking behavior of the operators. They opined that the absence of sustained economic development and growth despite huge aggregate and public investment was partly attributed to inefficiency of public investment and culture of corruption and misspent natural resources. To promote high and sustainable level of economic growth and development, government need to reduce or eliminate the culture of rent seeking, support private investment and entrepreneurship by investing on infrastructures and human development, and should sustain the current effort aimed at strengthened the financial sectors. Investing in infrastructure and human capital would boost economic growth and development and productivity.

\subsection{The Research Problem}

The indentified research problem for this paper is poor management of assets and liabilities resulting from poor investment policy in the banking industry. This has led to the high degree of non-performing loans and advances, illiquidity in the system, distress and liquidation of financial institutions loss of money by investors and depositors.

The Table 1 below shows the number of liquidated distressed banks in Nigeria

Table 1. Liquidated banks in Nigeria

\begin{tabular}{lll}
\hline SN & YEAR & NUMBER OF BANKS \\
\hline 1 & Pre-independence & 22 \\
2 & 1992 & 3 \\
3 & 1994 & 4 \\
4 & 1998 & 26 \\
5 & 2005 & 14 \\
\hline
\end{tabular}

Source: CBN, 2002, 2006 Annual Reports 
There was clear evidence of mismatch of assets and liabilities. The banks financed long-term projects with short term funds thereby created illiquidity problem. According to 2005 Central Bank of Nigeria report, the total assets to total available funds of distressed banks was $124.09 \%$ in 1995 , and $154.47 \%$ in 1996 . The industry position was $178.27 \%$ and $176.23 \%$ in 1995 and 1996b respectively. The position of the unsound banks was $2514 \%$ in 2003 and marginally unsound bank was $159.67 \%$ while the industry was $207.10 \%$. In 2004 , the position was $885.87 \%$ for the unsound banks, $186.67 \%$ for the marginally unsound banks while the industry was $223.64 \%$. The objective of this paper is to assess the investment policies in the banks with a view to suggesting better policy for better management of assets and liabilities for distress avoidance and resolution in the banking industry. The pertinent research question is: To what extent are the existing investment policies of banks assisting in the quality of management of assets and liabilities in the Nigerian banking industry

The establishment of Central Bank of Nigeria in 1959 gave respite. However; the reoccurrence of financial distress and bank failures between 1989 and 1998 was of greater intensity, both in scope and in depth. They presented the rating of Nigeria banking industry as at June 302002 as shown in Table 2 below.

Table 2. Bank ratings as at June 2009

\begin{tabular}{lll} 
RATING & \multicolumn{2}{c}{ NUMBER OF BANKS } \\
\hline & MARCH & JUNE \\
\hline Very Sound & 1 & - \\
Sound & 29 & 22 \\
Satisfactory & 45 & 53 \\
Marginal & 6 & 8 \\
Unsound & 8 & 6 \\
\hline
\end{tabular}

Source: CBN/NDIC Technical Committee on Supervision (2002)

The table shows that three were 14banks which were marginal and unsound. They explained that their share of industry assets and deposits were 13.4percent and 13.1 percent respectively. The industry ratio of non-performing credit to total was 21.4 percent. Thus the assets and deposit figures were below the systemic distress level of 20 and 15 percent of industry assets and deposits held for distress banks respectively. In addition the industry credit classified as non-performing was less than 35percent as defined in the framework for contingency planning for banking system distress and crises which took effect from $1^{\text {st }}$ July 2002. They gave the following as reasons for distress: (a) the role of management which was below tolerable standard. (b) the regulatory authorities failed to act at the appropriate time to avoid the losses recorded. (c) The macroeconomic environment which resulted into sluggish growth experienced in the economy. (d) Risk of contagion through their foreign affiliate and correspondent banks that could not pay back amount held in foreign currency on behalf of the local banks. (e) poor corporate governance (f) the poor quality of credit administration which resulted into non-performing loans and advances. (g) portfolio mismatch by borrowing short and lending long which impaired liquidity in the industry. They recommended consolidation through mergers and acquisition and the application of information and communication technology in the industry.

Statement of Hypotheses: The hypotheses formulated for this work are in null form:

1). Investment policies do not affect assets and liabilities management in the banking industry

2). Growing assets more than liabilities do not have negative impact on liquidity in the banking industry.

3). Acquiring adequate fixed assets for productivity enhancement does not have positive impact on tax benefits and fund retention in the banking industry.

\section{Literature Review}

Relevant literature of work done by researchers which are related to this work were reviewed as follows:

\subsection{Assets and Liability Management in Banks}

AllBankingSolution.com (2000) analyzed assets and liabilities management as a comprehensive dynamic framework for measuring, monitoring and managing the market risk of a bank. It is a tool that enables bank management to take business decisions in a more informed framework with an eye on the risks that bank is exposed to. It is an integrated approach to financial management, requiring simultaneous decisions about the type of amounts of financial assets 
and liabilities. According to Sayeed and Hogne (2009) banks profitability is of utmost concern in modern economy. Banks are in a business to receive deposits or liabilities and to issue debt securities on the one hand and create or invest in assets on the other hand. Commercial banks incure costs for their liabilities and earn income from their assets. This profitability of banks is directly affected by management of their assets and liabilities. In addition, different market and macroeconomic factors also influence the ability of the banks to make profits. According to Charumathi (2008),banks are always aiming at maximizing profitability at the same time trying to ensure sufficient liquidity to repose confidence in the minds of the depositors on their ability in servicing the deposits by making timely payment of interest/returning them in due dates and meeting all other commitments as agreed upon. To achieve these objectives, it is essential that banks have to monitor, maintain and manage their assets and liabilities portfolios in a systematic manner taking into account the various risk involved in these areas like the interest rate risk, operation risk and gap analysis.

In analyzing assets and liability management, Bank of America (2005) defines liquidity as the availability of funds, or assurance that funds will be available, to honour all cash outflows commitments as they fall due. These commitments are generally met through cash inflows, supplemented by assets readily convertible to cash or through the institutions capacity to borrow. The risk of illiquidity may increase if principal and interest cash flows related to assets, liabilities and off-balance sheet items are mismatched. Managing liquidity is a fundamental component in the safe and sound management of all financial institutions.

Sound liquidity management involves prudentially managing assets and liabilities both as to cash flow and concentration to ensure that cash inflows have an appropriate relationship to approaching cash outflows. This needs to be supported by a process of liquidity planning which assesses potential future liquidity needs, taking into account changes in economic, regulatory or other operating conditions. Such planning involves identifying known, expected and potential cash outflows and weighing alternative asset/liability management strategies to ensure that adequate cash inflows will be available to the institution to meet these needs. They highlighted the objectives of liquidity management as: (a) honoring all cash outflow commitment on an ongoing, daily basis (b) avoiding raising funds at market premiums or through the forced sale of assets (c) Satisfying statutory liquidity and statutory reserve requirements. A comprehensive liquidity and statutory reserve requires (a) establishing and implementing sound and prudent liquidity and funding policies. (b) Developing and implementing effective techniques and procedures to monitor measure and control the institutions liquidity requirement and position. Sound and prudent liquidity policies set out the sources and amount of liquidity required to ensure it is adequate for the continuation of operations and to meet all applicable regulatory requirements. These policies must be supported by effective procedures to measure, achieve and maintain liquidity. They averred that factors influencing an institution's operating liquidity include: (a) cash flows and the extent to which expected cash flows from maturing assets and liabilities match and (b) the diversity, reliability and stability of funding sources, the ability to renew or replace deposits and the capacity to borrow. For regulatory purposes an institution is required to hold a specific amount of assets classed as "liquid", based on its deposit liabilities. Generally, undue reliance should not be placed on these assets, or those formally pledged for operating purposes other than as a temporary measure, as legally they may not be available for encashment if needed. In assessing the adequacy of liquidity, each institution needs to accurately and frequently measure: (i) the term profile of current and approaching cash flows generated by assets and liabilities, both on-and off-balance sheet.(ii) the extent to which potential cash outflows are supported by cash inflows over a specified period of time, maturing or liquefiable assets, and cash in hand. (iii) the extent to which potential cash outflows may be supported by the institution's ability to borrow or to access discretionary funding sources (iv) the level of statutory liquidity and reserves required and to be maintained.Essentially,operating liquidity is adequate if the institution's approaching cash inflows supplemented by assets readily convertible to cash or by an institution's ability to borrow are sufficient to meet approaching cash outflow operations. In this context, because the timing and amount of these cash flows are not completely predictable because of risks such as credit defaults, and events including honouring customer drawdown on credit commitment, deposit redemptions, and prepayments, either on mortgages or term loans, sound and prudent liquidity policies must deal with this uncertainty by carefully controlling the maturity of assets, ensuring assets are readily convertible to cash, or securing sources to borrow funds. Liquidity is very essential for the sustainability of business in the banking industry. Liquidity planning is assessing potential future liquidity needs,taking into account changes in economic, regulatory or other operating conditions and weighing alternative asset/liability management strategies to ensure that adequate cash inflows will be available to an institution to meet these needs.

Central Bank of Nigeria (CBN) (2004:72) explained that banking institutions occupy a central position in the financial system in any country and for the banks to perform efficiently and contribute meaningfully to the 
development of the economy; the industry must be safe and sound. The absence of former banking legislation and a regulatory agency such as a central bank, the rudimentary nature of the banking system, and the poor management of Nigerian banks contributed to the distress. The establishment of Central Bank of Nigeria in 1959 gave respite. However; the reoccurrence of financial distress and bank failures between 1989 and 1998 was of greater intensity, both in scope and in depth.

They gave the following as reasons for distress: (a) the role of management which was below tolerable standard. (b) the regulatory authorities failed to act at the appropriate time to avoid the losses recorded. (c) The macroeconomic environment which resulted into sluggish growth experienced in the economy. (d) Risk of contagion through their foreign affiliate and correspondent banks that could not pay back amount held in foreign currency on behalf of the local banks. (e) poor corporate governance (f) the poor quality of credit administration which resulted into non-performing loans and advances. (g) portfolio mismatch by borrowing short and lending long which impaired liquidity in the industry. They recommended consolidation through mergers and acquisition and the application of information and communication technology in the industry.

\subsection{Banking Crisis: Causes, Early Warning Signals and Resolution}

Alashi (2002:49-66) stated that a bank that is illiquid or insolvent or both is distressed and therefore in crisis. That if many banks in a country are distressed to the extent that it becomes systemic, the country can be said to be having banking crisis. Banking crisis becomes severe when a bank reveals most of all of the following conditions: (a) gross undercapitalization in relation to the level and character of business. (b) high level of non-performing loans to total loans. (c) illiquidity reflected in the inability to meet customers cash withdrawals and persistent overdrawn with CBN. (d) low earnings resulting in huge operational losses. (e) weak management as reflected by poor asset quality, insider abuse fraud including unethical and unprofessional conduct, squabble and high turnover. He emphasized poor lending and borrowing culture as contributors to distress in the system. He presented the Table 3 below which shows detailed analysis of quality of bank lending between 1989 and 2001 to support his argument.

Table 3. Asset quality of banks from 1989 to 2001

\begin{tabular}{lllllll}
\hline & $\begin{array}{l}\text { Loans \&Advances } \\
\text { (N'billion) }\end{array}$ & & \multicolumn{2}{l}{$\begin{array}{l}\text { Non-Performing } \\
\text { Advances (N'billion) }\end{array}$} & \multicolumn{2}{l}{$\begin{array}{l}\text { Loans } \\
\text { Loan to Total } \\
\text { Advances (\%) }\end{array}$} \\
\hline Year & Industry & Distressed & Industry & Distressed & Industry & Distressed \\
\hline 1989 & 23.1 & 4.3 & 9.4 & 2.9 & 40.8 & 67.1 \\
1990 & 27.0 & 6.4 & 11.9 & 4.7 & 44.1 & 72.8 \\
1991 & 32.9 & 5.4 & 12.8 & 4.1 & 39.0 & 76.5 \\
1992 & 41.4 & 15.7 & 18.8 & 6.8 & 45.5 & 43.0 \\
1993 & 80.4 & 25.3 & 32.9 & 14.7 & 41.0 & 58.0 \\
1994 & 109.0 & 45.6 & 46.9 & 29.5 & 43.0 & 64.6 \\
1995 & 175.9 & 48.9 & 57.8 & 29.5 & 32.9 & 68.9 \\
1996 & 213.6 & 51.7 & 72.4 & 33.9 & 33.9 & 75.5 \\
1997 & 290.4 & 49.6 & 74.9 & 40.7 & 25.81 & 81.92 \\
1998 & 327.2 & 24.2 & 63.3 & 18.7 & 19.3 & 77.3 \\
1999 & 370.2 & 29.1 & 24.8 & 21.0 & 25.6 & 72.2 \\
2000 & 519.0 & 26.4 & 111.6 & 20.0 & 21.5 & 75.8 \\
2001 & 803.0 & 123.1 & 135.7 & 35.4 & 16.9 & 28.9 \\
\hline
\end{tabular}

Sourse: NDIC Annual Report 1989-2001

The problem of poor investment policies reflects in the table. According to Alashi, this is stem from poor corporate governance which led to four types of mismanagement in the industry which are (a) technical mismanagement involving inadequate policies, lack of standard practices, prevalence of over-extension, poor lending, mismatching of assets and liabilities, weak and ineffective internal control systems. (b) cosmetic mismanagement which consists of hiding past and current losses to buy time and stay afloat, looking, hoping and waiting for miracles to happen. (c) Desperate management is a condition where bankers see themselves in danger to declare, among others, capital reduction, operational loss and no dividends. (d) Fraud is part of the delinquent features that turn good bank managers into bad ones. He explained the implication of banking financial distress to the Nigerian economy as economic disequilibrium and distortion which if not properly managed could portend doom and lead to economic depression. In his concluding remark, Alashi stated that Nigeria witnessed systemic banking crisis from 1929 to early 1950s and a generalized banking distress from 1989 to 1998. It was established that the closed banks accounted for 
between 52 percent and 100 percent of the non-performing loans as at the date of closure. That the early detection and timely application of appropriate measures are crucial for effective management of banking crisis.

\subsection{The Causes of Financial Distress in Local Banks in Africa and Implications for Prudential Policy}

Brownbridge (1998:2-28) stated that banks can provide benefits to the domestic economies but they also present risks, with many having suffered financial distress and bank failure as a result of non-performing loans. The severity of bad debt problems was attributable to moral hazard on bank owners and the adverse selection of bank owners, with many banks pursuing imprudent lending strategies, in some cases involving insider lending. He defined them as financially distressed when they are technically insolvent and illiquid. Moral hazards or an adverse incentive is a concept with relevance to a variety of principal agent relationships characterized by asymmetric information. Brownbridge sees the moral hazard as the adverse incentives on bank owners to act in ways which are contrary to the interests of the banks creditors (mainly depositors or the government if it explicitly or implicitly insures deposits), by undertaking risky investment strategies (such as lending at high interest rates to high-risk borrowers) which, if unsuccessful, would jeopardize the solvency of the bank. Bank owners have incentives to undertake such strategies because, with limited liability, they bear only a portion of the downside risk but stand to gain through higher profits a large share of the upside risk. In contrast, the depositors (or the deposit insurers) gain little from the upside risk but bear most of the downside risk. The inability of depositors to adequately monitor bank owners, because of asymmetric information and free-rider problems, allows the latter to adopt investment strategies, which will entail higher level of risks (not fully compensated for by deposit rate risk premium), than depositors would prefer. Brownbridge concluded that many of the local banks set up in Kenya, Nigeria, Uganda and Zambia have been closed down or taken over by their Central Bank because of insolvency and illiquidity caused by non-performing loans. The severity of bad debt problems was attributable to problem of moral hazard and adverse selection.

\subsection{Incentives and the Resolution of Bank Distress}

Glaessner and Mas (1995:53-76) argued that insolvent banks have precipitated recurring problems in many developing countries. Bad credit administration due to poor or non-availability of investment policies has been a major cause of financial distress. In many cases, policymakers have implemented preventive measures designed to avert distress rather than remedial measures intended to resolve crises once they occur. They averred that to be efficient, reliable and credible, a policy framework for resolving bank distress must establish incentives for all concerned parties; incentives that preserve financial discipline, induce cooperative solutions, and protect the rights of claimants (by differentiating liability holders according to their seniority and the date of their claims). In suggesting mechanism for handling bank distress, Glaessner and Mas stated that by its nature, the framework for preventive measure must be established before financial crises occur and must be clear,consistent,and credible. They recommended two strategies for resolution. (a). Bank rehabilitation by restoring solvency through recapitalization, restoring profitability by restructuring the institutions policies, and upgrading management. (b) Bank liquidation through the forced sales of bank assets once operations have been permanently terminated through the legal system.

\subsection{Corporate Governance and Sustainable Performance Growth}

Al-faki (2005:29) stated that stability and prosperity of any economy is to a large extent dependent on the integrity of its business and markets, and that corporate governance not only contributes to the growth and financial stability of corporate enterprises, but also promotes financial markets integrity and economic efficiency. That high quality financial information is important from a capital market perspective, given the amount of debt held by most governments. High quality information is required for the reason of accountability, because they are entrusted with management of assets and liabilities that have built up over decades. CBN (2006:1-20) in avoiding grave financial scandals and collapse of institutions introduced code of corporate governance for banks in Nigeria post consolidation and to ensure the four pillars of corporate governance of accountability, fairness, transparency and independence are in place to protect assets and liabilities of the institutions.

\subsection{Gap in the Study}

The major gap discovered in the relevant literature reviewed is that the studies were basically theoretical and their recommendations were also based on the same notion. The work that used ratios and percentages to analyze the situation is the work of Alashi (2002). This work is designed to fill the gap by ensuring the work is empirical and descriptive. The work went further to base the decision on theoretical framework. This is based on current events in the financial sector. 


\section{Methodology}

The study is basically empirical and descriptive work involving the study of the samples chosen from the population to assess the investment policies in the banks with a view to derive a better policy for better management of assets and liabilities in the banking industry. The population for this study is the banking industry in Nigeria which is made up of the 24 consolidated universal banks, all the discount institutions, five regulatory bodies that have direct link with banking business in Nigeria viz: the two supervisory and regulatory authorities-CBN and NDIC that issue monetary policies for the industry and regulate the operations of the industry, two professional bodies that have been regulating ethics in the industry for more than a decade and support the CBN and NDIC in policy and merger issues in the industry-ICAN and CIBN and the capital market regulatory body that handles the industry capital floating and daily trading of their shares-Nigerian Stock Exchange (NSE). The sample size is 29 institutions which covers the 24 consolidated universal banking institutions and the 5 regulatory bodies in the Nigerian banking industry. The sampling technique adopted is judgmental/purposive so as to ensure all the institutions are fully represented for the purpose of getting macro data and for full coverage of the institutions and reliability of the work. Corporate questionnaire was administered to each corporate institution in the sampled population. 29 corporate questionnaires were administered. The questionnaire was close ended and designed in a simple-to-answer form with liker scale in use: Strongly Agree(SA), Agree(A), Disagree(D), Strongly Disagree(SD) and undecided(UD) with scores 5,4,3,2 and 1 respectively. Out of 29 questionnaires administered, 28 were duly completed and returned. This is a percentage of 96.55 percent and was considered adequate for the work. Multivariate Analysis of Variance (MANOVA) was adopted to compute the result of the field work. MANOVA is used when there is more than one dependent variable which should be related in some way, or there should be some conceptual reason for considering them together.MANOVA compares the groups and tells whether the mean difference between the groups on the combination of dependent variables is likely to occur by chance. For the analysis of this work as to the suitability of all the data in the questionnaire to solve the problem of distress, each statement was regarded as dependent variable, while the banking institutions were divided into three groups to meet the conditions of MANOVA. Statistical Package for Social sciences was used to compute the results.

For the purpose of using MANOVA and following the rule, the respondents-sampled population were grouped into three independent variables using the profit levels as follows: Very strong bank with average profit before tax of \$20million and above, Strong bank with average profit before tax of between \$10million and $\$ 19$ million and Slightly Strong bank with average profit before tax of between $\$ 1$ milion and $\$ 9$ million.

$\begin{array}{ccc}\text { Types of Banks } & \text { Value label } & \text { Nvalue } \\ 1 & \text { Slightly strong } & 13 \\ 2 & \text { Strong } & 6 \\ 3 & \text { Very Strong } & \underline{9} \\ & & \underline{28}\end{array}$

The theoretical approach for the work is two-fold: The first is the contingency approach which forces managers to recognize that organizations are systems made up of interdependent parts and that a change in one part will affect other parts, hence managers must find different ways to fit different situations. The contingency approach seeks to match different situations with different methods. This is Fielder's contingency theory which asserts that group performance is contingent on the leaders' psychological orientation and on three contextual variables: group atmosphere, task structure, and leaders' power. Therefore effective Asset and liability management is a contingency approach which a manager needs to implement in a situation of distress and liquidity problem. The second theory is PRIMO-F business growth model of Durhan University Business School, which makes an organization and its management effective. The model demonstrated that an effective organization needs to fulfill the following equation:

Organizational Growth Effectiveness $=$ Performance to date $\times$ Potential for the future. They opined that at its simplistic the model can be used as an agenda for change, when with the management team and between them they score the business and action. The two theories set the manager to look at the best approach that will take the industry out of distress, having analyzed that poor asset and liabilities management has been a bane the problem. The PRIMO-F business growth model is very relevant to achieving growth by implementing the strategy of effective assets and liabilities management to achieve good performance for sustainability and stability. 
Analysis of results/output from Multivariate Analysis of Variance

\section{1) Descriptive Statistics.}

Eight dependent variables representing questions picked for the testing of the hypotheses have the following statistical results.

\begin{tabular}{lll}
\hline Dependent Variable & Mean & Standard Deviation \\
\hline $\begin{array}{l}\text { 1. Security nature and management of Advances } \\
\text { 2. Strong relationship between investment policy }\end{array}$ & 2.8214 & .6118 \\
and effective management of assets and liabilities & & .7310 \\
$\begin{array}{l}\text { 3. Liquidity problem and growing assets more than } \\
\text { liabilities }\end{array}$ & 2.5357 & .5357 \\
$\begin{array}{l}\text { 4. Good capital budgetary system and liquidity mgt } \\
\begin{array}{l}\text { 5. Good investment appraisal system and capital } \\
\text { base }\end{array}\end{array}$ & 4.6429 & .4880 \\
$\begin{array}{l}\text { 6. Depositors money for asset purchase and distress } \\
\text { 7. Adequate fixed assets and tax benefits for fund }\end{array}$ & 4.2857 & .6341 \\
retention & & \\
8. Compliance with monetary policy and distress & 4.8571 & .8483 \\
resolution & & .8262 \\
\hline
\end{tabular}

Table 4. Assessment of the relationship between investment policy and management of assets and liabilities for performance sustainable growth in the banking industry

\begin{tabular}{|c|c|c|c|c|c|c|c|}
\hline & MEAN & SD & SA & A & $\mathrm{D}$ & SD & UD \\
\hline $\begin{array}{l}\text { [1] Large amount of non-performing loans and } \\
\text { advances in the banking industry can be attributed } \\
\text { to the unrealizable nature of the securities and not } \\
\text { on the management of these advances. }\end{array}$ & 2.8214 & .6118 & $0 \%$ & $10.7 \%$ & $60.7 \%$ & $0 \%$ & $28.6 \%$ \\
\hline $\begin{array}{l}\text { [2] There is a strong relationship between good } \\
\text { investment policy and effective management of } \\
\text { assets and liabilities as they enhance returns on } \\
\text { investment and liquidity availability. }\end{array}$ & 4.6429 & .7310 & $75.0 \%$ & $17.9 \%$ & $3.6 \%$ & $3.6 \%$ & $0 \%$ \\
\hline $\begin{array}{l}\text { [3] A facility approved for a bank customer can } \\
\text { become unrealizable immediately after } \\
\text { disbursement due to the appraisal system. }\end{array}$ & 4.2143 & .9567 & $42.9 \%$ & $46.4 \%$ & $3.6 \%$ & $3.6 \%$ & $3.6 \%$ \\
\hline $\begin{array}{l}\text { [4] Growing assets more than liabilities do not } \\
\text { create liquidity problem in the banking operations } \\
\text { and can not lead to financial distress. }\end{array}$ & 2.5357 & .5762 & $0 \%$ & $3.6 \%$ & $46 . \%$ & $50 \%$ & $0 \%$ \\
\hline $\begin{array}{l}\text { [5] A good capital budgetary system is a necessity } \\
\text { for liquidity management and timely replacement of } \\
\text { productive assets. }\end{array}$ & 4.6420 & .4880 & $64.3 \%$ & $35.7 \%$ & $0 \%$ & $0 \%$ & $0 \%$ \\
\hline $\begin{array}{l}{[6] \text { The institution and implementation of good }} \\
\text { investment appraisal system in the banking industry } \\
\text { will help to determine when to shore up the capital } \\
\text { base in relation to business activities and its growth. }\end{array}$ & 4.4285 & .6341 & $50 \%$ & $42.9 \%$ & $7.1 \%$ & $0 \%$ & $0 \%$ \\
\hline $\begin{array}{l}\text { [7] Using depositors' money to buy assets for } \\
\text { operational activities is a bad investment policy, } \\
\text { which can lead to financial distress. }\end{array}$ & 4.2857 & 1.1501 & $60.7 \%$ & $25 \%$ & $0 \%$ & $10.7 \%$ & $3.6 \%$ \\
\hline $\begin{array}{l}\text { [8] It is a good investment policy for a bank to buy } \\
\text { adequate fixed assets for operational activities in } \\
\text { order to enjoy tax benefits for reduction in tax } \\
\text { liability and retention of liquid fund. }\end{array}$ & 3.8571 & .8483 & $14.3 \%$ & $67.9 \%$ & $10.7 \%$ & $3.6 \%$ & $3.6 \%$ \\
\hline $\begin{array}{l}\text { [9] Compliance with Central Bank of Nigeria } \\
\text { monetary policy by banks on liquidity ratio can be a } \\
\text { factor for resolving distress otherwise distress } \\
\text { will continue to be a terminal disease in the } \\
\text { banking industry in the absence of liquidity. }\end{array}$ & 4.3571 & .8262 & $46.4 \%$ & $50 \%$ & $0 \%$ & $0 \%$ & $3.6 \%$ \\
\hline
\end{tabular}

Source: Field Survey, 2010 
From the descriptive statistics and on the five scale point, the means of all the dependent variables are above 2.5 average and the standard deviation of each is below one scale point with the exception of depositor money for asset purchase with 1.1501 which does not show much dispersion from the mean of 4.2857. The results show the following (a). large amount of non-performing loans and advances can be attributed to the poor management of the advances in the three groups of banks; (b). good investment policy and effective management of assets and liabilities will enhance returns on investment and made liquidity available in the three groups of banks; (c). growing assets more than liabilities can create liquidity problem in the three groups of banks which will lead to financial distress; (d). a good capital budgetary system is good for liquidity management and timely replacement of assets in the groups of banks; (e) Institution of good investment appraisal system will help to determine when to shore up capital base in the three groups of banks; (f) Using depositors' money to buy assets for operational activities is a bad investment policy, which can lead to financial distress in the groups of banks; (g) it is a good investment policy for a bank to buy adequate fixed assets for operational activities in order to enjoy tax benefits for reduction in tax liability and retention of liquid fund in the three types of banks and (h) compliance with Central Bank of Nigeria monetary policy on liquidity ratio can be a factor for distress resolution in the three groups of banks. The analysis shows that all the eight dependent variables are good for testing the hypotheses to determine the position of investment policies in the three groups of banks.

\section{2). Result of Hypotheses Testing}

Hypothesis 1: Investment policies do not affect asset and liabilities management in the banking industry.

The following statistical results were obtained using MANOVA with the use of statistical package for social sciences (SPSS) which produced the results in Table 4.

The respondents that disagreed to this statement is 89.3 percent, while the mean shows a figure of 2.8214 which is above the average of 2.5.The standard deviation is .6118 which is below one scale point. The multivariate test shows a Wilk's Lambda result of .963 which is above 0.05 which shows there is no difference among the groups of banks on a linear relationship and linear combination relative to the dependent variables to solve the problem poor assets and liabilities management in the three groups of banks. In the groups' means comparisons, the differences are insignificant as they are less than one scale point in each case (between 0.086-0.445) which means that the dependent variables are coherence in assets and liabilities management in the three groups of banks. The F test result is 7.653 which is higher than the tabulated of 3.38 .

The results obtained show that the null hypothesis is rejected and the alternate accepted which prove that investment policies in the groups of banks have significant impact in assets and liabilities management in the three groups of banks.

Hypothesis 2: Growing assets more than liabilities do not have negative impact on Liquidity in the banking industry.

The following statistical results were obtained using MANOVA with the use of statistical package for social sciences (SPSS). The percentage of respondents that disagreed with this statement is 96percent while the mean score is 2.5357 which is above the average of 2.5 and the standard deviation is .5357 which is below one scale point. The multivariate test is .966 in Wilk's Lamnda statistics which is higher than the significance level of 0.05 indicating homogeneity in the linear combination of the dependent variables and the groups of banks. The group means differences are insignificant (between 0.111-0.359) as they are less than one scale point in each case which means that the dependent variables will have significant impact on liquidity in situation of growing assets than liabilities in the three groups of banks. The F-test result is 3.408 which is higher than the tabulated figure of 3.38. The results obtained show that the null hypothesis is rejected while the alternate is accepted meaning that growing assets more than liabilities will have negative impact on liquidity in the banking industry.

Hypothesis 3: Acquiring adequate fixed assets for productivity enhancement does not have positive impact on tax benefits and fund retention in the banking industry. The following results were obtained through MANOVA with the use of statistical package for social sciences (SPSS). The percentage of respondents that disagreed with this statement is 82.2 percent.The mean score is 3.8571 which is more than the average of 2.5 while the standard deviation is .8483 which is below one scale point. The multivariate test is .960 which is more than the siginificant level of 0.05 indicating homogeneity in the linear combination of the groups of banks and the dependent variables. The group means differences are insignificant as they are less than one scale point in each case (between 0.034 and 0.256) which means that the dependent variables will have significant impact on liquidity in situation of growing assets than liabilities in the three groups of banks. The F-test result is 4.414 which is more than 3.38 . 
The results obtained show that the null hypothesis is rejected while the alternate is accepted which means that acquiring adequate fixed assets for productivity enhancement will have positive impact on tax benefits as tax benefits will reduce tax liability and ensure funds are retained in the organization.

\section{Conclusion}

The research has shown that poor management of assets and liabilities has been a major factor for financial distress and institutions liquidation in the banking industry. High percentage of loans and advances are not performing which has led to liquidity crisis and inability to compete effectively. They grow loans and advance more than what their deposits could accommodate thereby borrowing from Central Bank of Nigeria to accommodate the excess. They operate very weak investment policies and do not comply with Central Bank of Nigeria monetary policy. Purchasing of fixed assets is not targeted towards obtaining tax credits/benefits in order to retain funds in the system. This has made many investors and depositors to lose their money in the distressed and liquidated banks. From the theoretical analysis, it was discovered that economic performance in Nigeria over the years has been abysmal. The economic performance indices of inflation, unemployment, growth and exchange rate have been on the negative. The government has not been able to provide enabling environment to sustain economic growth. These factors have affected the banking industry to continue to be the bedrock of the nation. Nigeria has turned to a consuming economy from productive economy of 1960s (Onoh, 2002)

\section{Recommendations}

The following recommendations are pertinent to resolving this problem (1) The industry and regulators should institute a good and sound investment policy for batter management of assets and liabilities in the banking industry (2) The government should invest in infrastructural and human capital development that would help to boost economic growth, development and productivity which will in effect strengthened the operations of the financial sector. (3) the banks need to institute effective risk asset management in their operations and incorporate Central Bank Prudential guidelines for quality assets and earnings. (4) there should be quality training for the credit analyst to avoid non-performing advances and loss of income. (5) Good surveillance of the operations and knowledge of the operations of each bank by the regulatory authorities will help to determine when to shore up their capital base. (6) The members of the parliament i.e. Senate and Federal House of Representatives should pass a law which will give automatic powers to the financial institutions to foreclose securities pledged for any facility without recourse to the customers after demand for payment has lapsed. This will give the borrowing customers commitment to the serving and repayment of money borrowed. (7) The banking industry should ensure strict compliance with Central Bank of Nigeria on percentage of total loans and advances against total deposits so as to retain enough liquidity in the organization. (8) The banking industry should implement tax planning to ensure adequate qualifying capital expenditure are acquired to enjoy tax credit for liquidity retention in business in tax assessment. (9) The government should ensure a dynamic business environment by providing the necessary infrastructural facilities that will support business to operate successfully as going concerns, and achieve sustainable growth.

\section{References}

Alashi, S.O. (2002). Banking Crisis: Causes, Early Warning Signals and Resolutions. NDIC Quarterly, 12.

Al-Faki, M. (2005, July 25). Good corporate governance:essentially for leadership and Performance Excellence. The Guardian, Monday, 29.

Banks and Other Financial Institutions Act. (1991). Definition of Banks S.62.

Brownbridge, M. (1998). The Causes of Financial Distress in Local Banks in Africa and Implications for Prudential Policy. United Conference on Trade and Development (UNCTAD) Publications, pp. 2-28.

CBN \& NDIC. (1995). Definition of Distress and Analytical Framework-Distress in the Nigerian Financial Services Industry. Collaborative study. NDIC Publication.

Central Bank of Nigeria (CBN). (2004). A Case Study of Distressed Banks in Nigeria. Research and Statistics Department, Central Bank of Nigeria, Abuja.

Central Bank of Nigeria (CBN). (2006). Economic Report for the first half of 2006. Research and Statistics Department, Central Bank of Nigeria, Abuja, pp.10-13.

Ekpo, A. H., \& Umoh, O. J. (2012). An overview of the Nigeria Economic Growth and Development. Online Nigeria Community Portal of Nigeria. 
Glaessner, T., \& Mas, I. (1995). Incentives and the Relations of Bank Distress. The World Research Observer, 10(1), 53-73. http://dx.doi.org/10.1093/wbro/10.1.53

Olalusi, F. (1992). Introduction to Banking. Evans Brothers (Nigeria Publications) Ltd. Jericho Road, P.M.B.5164, Ibadan, pp. 13-59.

Olulana, O.J.A. (2000). The law and Practice of Banking, Collaterial,Securities and Mortgages. Diversities Enterprises, Unity House, Marina, Lagos 1st Edition, p.16

Onoh, J.K. (2002). Dynamics of money banking and finance in Nigeria-An emerging market. Astra Meridian Publishers, P.O.BOX 5350, Aba, pp. 15-30.

Udah, E.B., \& Obeguagu, R. (2011). Constraints to Economic Development and Growth in Nigeria. European Journal of Scientific Research, 65(4), 581-593.

USAID. (2012). Economic Growth and Environment. United States Agency International Development Publication, Abuja, Nigeria.

\section{Appendix 1}

COVENANT UNIVERSITY

DEPARTMENT OF ACCOUNTING, KM 10, IDI-IROKO ROAD, OTA.

OGUN STATE.

\section{CORPORATE QUESTIONNAIRE}

This research work is aim at evaluating the relationship between Investment Policy and Management of Assets and Liabilities for Performance Sustainable Growth in the Nigerian Banking Industry. Please note that information provided will be treated with strict confidentiality. Feel free to answer the questions to the best of your knowledge.

SECTION A: Contains questions on your personal data.

Tick the appropriate box as applicable to your organization.

[1] Our management system is:
A. Strategic Management
B. Tactical Management
C. Operational Management

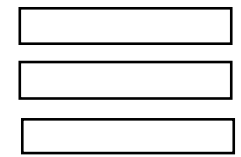

[2] Period a staff can serve the organization without adverse behaviour/record:
A. 0-5years
B. 6-10years
C. Above 10 years

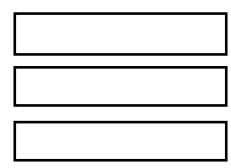

[3] The Planning Process in our organization can be Classified as:
A. Participatory
B. Top-Bottom
C. Bottom-Top

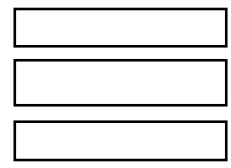

[4] Minimum Qualification for employment:

i. Into Junior staff: SSCE OND

ii. Into Senior staff/Top Management;

\section{HND/Bsc}

HND/Bsc/Professional Qualification

Experience
On the job training
Promotion 


\section{SECTION B}

This section is to evaluate the relationship between investment policy and management of assets and liabilities for performance sustainable growth in the banking industry.

\begin{tabular}{lllll}
\hline SA & A & DA & SDA & UD
\end{tabular}

[1] Large amount of non-performing loans and advances in the banking industry can be attributed to the unrealizable nature of the securities and not on the management of these advances.

[2] There is a strong relationship between good investment policy and effective management of assets and liabilities as they enhance returns on investment and liquidity availability.

[3] A facility approved for a bank customer can become unrealizable immediately after disbursement due to the appraisal system.

[4] Growing assets more than liabilities do not create liquidity problem in the banking operations and can not lead to financial distress.

[5] A good capital budgetary system is a necessity for liquidity management and timely replacement of productive assets.

[6] The institution and implementation of good investment appraisal system in the banking industry

will help to determine when to shore up the capital base in relation to business activities and its growth.

[7] Using depositors money to buy assets for operational activities is a bad investment policy, which can lead to financial distress.

[8] It is a good investment policy for a bank to buy adequate fixed assets for operational activities in order to enjoy tax benefits for reduction in tax liability and retention of liquid fund.

[9] Compliance with Central Bank of Nigeria monetary policy by banks on liquidity ratio can be a factor for resolving distress otherwise distress will continue to be a terminal disease in the banking industry in the absence of liquidity. 